\title{
Multicultural and Intercultural Common Heritage in Transylvania
}

\author{
Ildikó-Csilla Takács \\ Business Administration Doctoral School, Bucharest University of Economic Studies, Bucharest, Romania
}

\section{Email address:}

mirthrubin@yahoo.com, csillatakacs12gmail.com

\section{To cite this article:}

Ildikó-Csilla Takács. Multicultural and Intercultural Common Heritage in Transylvania. International Journal of Education, Culture and Society. Vol. 2, No. 5, 2017, pp. 147-157. doi: 10.11648/j.ijecs.20170205.12

Received: February 18, 2017; Accepted: February 27, 2017; Published: October 31, 2017

\begin{abstract}
The focus of this paper is the examination of multicultural and intercultural values along with the description of cultural heritage in order to support the hypothesis that these principles have an impact on educational cooperation practices and semantic features of cultural entities. The study presented in this paper will show that intercultural awareness is crucial, since a nation passes on its culture to its youth so as to preserve its national character for the future. My purpose is to develop consciousness of the Transylvanian people belonging to the Romanian, Hungarian and the Saxon cultures, as they became the melting pot of all these forces, merging the Transylvanian character in a truly national culture. Therefore, teaching and learning about intercultural communicative competence is a challenge to raise students' awareness of their own culture, as well as to help them interpret and understand other cultures. It is not just a body of knowledge, but a set of practices requiring information, skills, attitudes which make what culture is: language that maintains discourse relations by providing, in a concise way, an ocean of information about how people conceptualize the world around them.
\end{abstract}

Keywords: Intercultural Awareness, Identity, Cultural Heritage

\section{Introduction}

The spirit of Transylvania finds expressions both in its language and its culture. The people stick to their cultural heritage instinctively and consciously, as they realize that their identity as a nation is thoroughly connected with it. Transylvania becoming conscious of its national identity, culture, language, traditions, history, and customs strives not only to retain these but is eager to see them flourish. One of its major preoccupations is to pass on its national culture to posterity. This preoccupation is identical to national selfpreservation, and it is for this reason that schools play a decisive cultural role in the life of nations.

However, the transmission of culture takes place not only in school settings, cultural organizations, and associations, but the press and the theatre also assume a key role in defining and spreading popular culture. The cultural development of the people is the result of the combined work of all these entities.

One of the important points in describing the field of cultural heritage is the relative complexity of the field under reflection. Cultural heritage includes heritage objects such as archaeological sites and museums, as well as newly defined or emerging areas of heritage such as folklore and cultural landscapes. The definition of cultural heritage is always shifting, and this has an impact on cultural cooperation practices. Moreover, typologies of cultural heritage have distinguished an absolute change and radical evolution in the last 25 years. According to the Council of Europe and UNESCO's World Heritage List the criteria for the categories include material and immaterial heritage, tangible and nontangible, sustainable, buildings and objects, continuities (canals, rivers, seaside, cultural routes, etc.), even people as 'treasures' are now key words for this area.

The definition used by UNESCO since the 1989 Recommendation on the Safeguarding of Traditional Culture and Folklore (http://portal.unesco.org/en) is as follows: "Folklore (or traditional and popular culture) is the totality of tradition-based creations of a cultural community, expressed by a group or individuals and recognized as reflecting the expectations of a community in so far as they reflect its cultural and social identity; its standards and 
values are transmitted orally, by imitation or by other means. Its forms are, among others, language, literature, music, dance, games, mythology, rituals, customs, handicrafts, architecture and other arts." or which "Exhibit an important interchange of human values over a span of time or within a cultural area of the world, on developments in architecture or technology, monumental arts, townplanning or landscape design."

Transylvania provides an important case in point: over 100 restoration or excavation sites were opened between 1996 and 2014, pushing the heritage budget to its highest level. The zone of Sibiu, marked by multiculturalism, preserves a rich cultural heritage formed partly during the medieval period and the Saxon migration to Transylvania, with a particularly remarkable ensemble of fortified churches and rural citadels. Since the 12th century, the south-east, the centre and the north of Romania have had over 200 Saxon villages. This rural built heritage has quickly degraded since the Saxon population started migrating to Germany. Sibiu thus sets a very good example of a framework that should make it possible to implement a policy of sustainable development, founded on cultural tourism, agriculture and traditional arts.

This study will focus on the art, folklore and music of the Romanian, Hungarian and Saxon cultures in Transylvania, on the semantic features of cultural entities and, hopefully, it will develop an awareness of the Transylvanian cultures along with an increased consciousness of one's own culture. The reason why I chose to examine multicultural and intercultural values is that this topic is mostly anthropocentric; it is focused on people, their behaviour, perceptions of their environment, their physical and emotional states, and their interaction with others. Furthermore, within each of the region the built heritage has played a distinctive role in helping to define the principles of society.

A further reason is that examination of multicultural values across languages helps us understand the way people think and gives us an invaluable insight into human psychology. This has wider implications than it may appear at first. When we set out to learn a new language, we are faced with a truly remarkable task. For it is not just the language we want to acquire, but also the immense world of culture, history, conventions and customs which we need to get to know in order to be able to reach the level of a native speaker of that particular language.

Although it is impossible to generalize with confidence about language and culture from a restricted study such as this one, the fact that multicultural and intercultural values may be at work in Transylvania would suggest that the cultural thinking might also function in other languages to other nations. If Transylvanians are aware of the enrichment factors, which lie behind the Romanian, Hungarian and Saxon cultures, they will be able to better understand the cultural differences among nations; in addition, this will help students from a variety of backgrounds to develop respect for each other.

\section{The Cultural History of Transylvania}

Transylvania was first referred to in a Medieval Latin document in 1075 as Ultra Silvam, meaning 'beyond the forest', true to its name, since this region stretches across swelling hills decorated by a thick carpet of forest, superior in scale to every other European forest. The name was later changed to Transylvania (Trans meaning 'across, over, beyond').

Cluj-Napoca is considered to be the region's historical capital and has been inhabited since $200 \mathrm{BC}$; yet the first fortified walls around Cluj were built in the 13th century with watch towers, covering 17 acres of land. Transylvania was also ruled from Alba Iulia during its vassalage to the Ottoman Empire, and the seat of the Transylvanian Diet was moved to Sibiu for some time in the 19th century.

Economic policies, the ones of the Habsburg Empire during the Enlightened Despotism of Maria Theresa and of Joseph II., decisively contributed to the generation of a real communication network, generating small intellectual revolutions. In spite of the difference in mentality between Western Europe and Central and Eastern Europe, the intellectuals were thriving in regions where they succeeded in spreading the Enlightenment ideas, introducing realistic information in their communities, and were concerned with the understanding and translating literary, philosophical and political works.

Even though the Habsburg Empire included an enormous variety of areas inside its borders, encouraged their emancipation from the medieval mentality and passed legislation that imposed linguistic, cultural and religious diversity. The empire provided the minimum training to its people necessary for their economic development under the pressure of the German Enlightenment. Illiteracy of an important part of the communities was overcome for the first time in the years of the Enlightened Despotism (1780-1790). The normative restrictions of the Austrian state were aimed at developing the bourgeoisie and capitalism, gradually replacing traditionalism with modernization, and at providing quite uniform living standards in all the regions.

The historical region of Transylvania covers 16 presentday counties (județ), which include $99,837 \mathrm{~km}^{2}$ in central and northwest Romania. The 16 counties are Alba, Arad, Bihor, Bistița-Năsăud, Braşov, Caraş-Severin, Cluj, Covasna, Harghita, Hunedoara, Maramureș, Mureș, Sălaj, Satu Mare, Sibiu, and Timiș.

The political and governmental legacies left behind by the histories of the two empires, the Habsburg and the Ottoman; enable us to discover where the issue of interculturality has come from, how it survived, and what pedagogical role it might play today. 19th century concepts like ethnicity are still in circulation, thus justifying the necessity for the evaluation of the political and educational ideas in this area. The reference nationalism in the background emphasizes why multi- and intercultural education was a priori rejected in favour of mono-cultural and collectivist education. 


\section{The Transylvanian Art}

The fine arts in Transylvania followed two distinct traditions, the Byzantine tradition represented by the Romanian Transylvanians and the Western tradition characteristic to the Transylvanian Saxons and Hungarians. This allotment with stylistic interferences was caused by the rigorous iconographic programmes imposed by religion. However, in some Orthodox churches in Transylvania, we can see valuable works clearly influenced by western-type trends (the Gothic paintings at the Strei village church in Hunedoara County from the 14th century).

The wall paintings constitute one of the most imposing 14th century Byzantine-type mural compounds and a model for the wall painters in Transylvania integrated into real local schools of painting. Besides the archetypal models and the contemplative immobility canon, shared with the entire Orthodox Eastern world, Romanian paintings, wall-paintings, miniatures, liturgical embroidery cartoon, illuminations by Gavriil Uric ${ }^{1}$ in 1429 , the first known Romanian painter, have their own specific traits.

The Transylvanian Painting Collection, in the Brukenthal Museum $^{2}$ in Sibiu is one of the most noteworthy galleries of the eminent figures belonging to the Saxon patriciate, embracing a great number of portraits from the 16th to the 18th century, which are significant especially from a historical and documentary point of view. The present exhibit offers visitors the possibility to compare the main artistic movements and styles from the Renaissance to the Rococo. In addition, these works comprise the first lay portrait in the history of national painting, made by the painter Gregorius from Brasov, portraits by Jeremias Stranovius, a painter who worked in Transylvania, portraits by Johann Martin Stock, the most appreciated painter of the century from Sibiu, and works belonging to Franz Neuhauser, who settled in Sibiu.

The Brukenthal Museum also comprises an important decorative art collection embracing altars, sculptures, lay and religious silverware (dating from the 15 th century to the 18th century), glassware, oriental carpets and furniture, items of a special artistic value, their style and technique proving their origin in the Central-European space.

The total number of volumes of the Brukenthal Library reaches 280,000 of which 442 titles representing incunabula grouped in 382 volumes, including the library of the Dominican monastery and the library of a series of patrician families in Sibiu.

From among the portraitist and landscape artists of the 19 th century and the beginning of the 20th century I would like to mention Henri Catargi, Bertalan Székely ('The Corpse of Lajos II found after the Battle of Mohács', 'Dobozi', and the 'Court of László V'), Theodor Benedikt Sockl, Theodor Glatz, Heinrich Trenk, Misu Popp ('Tocile', Saint Nicholas Church), Carl Dörschlag, Arthur Coulin, Robert Wellmann, Fritz Schullerus, Octavian Smigelschi, Emerich Tamás, Imre Zsögödi Nagy and Friedrich Miess. Their paintings can be

[1] the Four Gospels is now in the Bodleian Library in Oxford

[2] http://www.brukenthalmuseum.ro/index_en.htm admired in Bucharest at the Romanian Literature Museum and the National Art Museum, as well as in museums in Arad, Braşov, Ploieşti, and Sibiu, as they all contributed to the Transylvanian culture with their work of art.

The absence of a truly artistic atmosphere in Transylvania, which had obliged so many artists to study and work abroad, began to be corrected at the end of the 19th century. It was then that Simon Hollósy founded an artists' settlement in Baia Mare with the cooperation of Thorma, IványiGrünwald, Glatz, Csók and Ferenczy. Although it was Hollósy who had recruited the young painters, Károly Ferenczy became their spiritual leader. On second thoughts, Baia Mare may be called the Hungarian Barbizon, as its effects on Hungarian painting can be comparable to those of the Barbizon and it implies for French art. Baia Mare actually produced open-air painting, achieving an independent and individual system of forms which was in no sense an imitation of the French school, and went far beyond the means of Bastien Lepage ${ }^{3}$. The value of the art of the Baia Mare School constitutes in presenting the Transylvanian countryside in all its beauty.

Travellers can also admire the Ethnographic Museum of Transylvania in Cluj-Napoca, a grand showcase of more than 50,000 objects on the life, habits and culture of Transylvania. Additionally, the National History Museum of Transylvania is a remarkable presentation of the history and civilisation from prehistoric times to the 20th century with excavations, weapons, ceramics, photos and books. The National Art Museum has an extremely valuable collection of old Romanian and European art works. Moreover, we can also admire the Teleki library in Targu Mures, which today contains a prosperous archive of 250,000 mathematical and scientific works. $(40,000$ of which were Samuel Teleki Count's private collection).

In Transylvania the sculpture was subordinated to the style of Catholic religious' values. Lack of involvement in Byzantine principles, characteristic of the $17^{\text {th }}$ and $18^{\text {th }}$ century, reached a peak in the $19^{\text {th }}$ century once the lay character asserted itself in the arts and the latter adapted themselves to modern life both in subject-matter (portrait and historical scene) and in techniques (easel painting) or artistic trends (Academism and Romanticism).

The greatest Hungarian sculptor in the $19^{\text {th }}$ century was János Fadrusz (1838-1903), whose most important creation was the monumental statue of King Matthias Corvinus, which stands in Cluj-Napoca and in Zilah is Fadrusz' famous statue of Baron Wesselényi. Fadrusz died at the early age of 45 , leaving behind not more than a dozen creations, these, however, have won lasting fame.

The Romanian sculptor, Constantin Brâncuşi (1876-1957) restructured by geometric simplification the whole $20^{\text {th }}$ century art. A few of his works are in the Romanian museums, i.e. Prayer, The Kiss, Miss Pogany, Wisdom of the Earth, etc. Noteworthy are also his monuments, consisting of the Endless Column, The Table of Silence and of the Gate of

[3] an artistic style that emerged from the later phase of the Realist movement 
Kiss, dedicated to the soldiers fallen in World War I. In sculpture outstanding artists were also Cornel Medrea (18891964) and Vida Géza (1913-1980) in monumental sculpturing, whose statues of great Romanian personalities are remarkable by spiritual profoundness.

How does the axis of the world appear in the Transylvanian village, the cradle of folk art and culture? Architecture provides a first answer. The human construction and the surrounding nature arise in a relationship of harmony, each being an extension into the other. Therefore, the peasant has been the architect, master builder and decorator of his own home. The house itself is usually a single-floor structure, seldom having two levels. In each region, a specific building material was used; wood was once the prevailing material but today it is used especially in mountainous areas; clay and brick for houses built in the plain, while stone is used in the mountains. The interior and the yard are not separated; they are connected by a sort of semi-sheltered veranda called prispa, which lines the façade, or even the sides and has a functional and decorative role alike. Everywhere in the country, where there are vineyards and orchards, the old prispa was changed into a colonnade, usually in the middle of the façade, ornately provided with carved pillars, girders and railings. In the mediaeval fortified dwellings, specific to the Balkan Peninsula, the cula acquired a distinctive note, so the last of the three or four floors was opened as a belvedere or look-out, which in the 18th century made their way into the Romanian zones.

In the Romanian villages the houses stand one beside the other but are separated by gardens and orchards, or they are scattered on the hills, and their white painting as well as the multicolored flowers surrounding them convey an air of tranquillity and liveliness. Unlike these, the Saxon houses are adjoining, forming one big wall overlooking the street, stern and detached from the community, they bespeak a rigorous spirit subordinated to geometry. The materials are the traditional ones, stone and red bricks, with a red clay tiled roof, which is a typical feature of the area.

Another element the Transylvanians focused on is the gate, as it has been a passage between the community space and the family one. The Székely Gate with a system of mythical symbols and richness of forms has been practiced for thousands of years and still inspires the Szeklers ${ }^{4}$ in creating their home environment and preserving their traditions even today. Most remarkably each gate has been a unique individual work of art, guarding the sanctuary of the home within. Several motifs are carved into the oak, such as the upward scrolling or spiralling lines, tree of life, sun as central motif, runic symbols, five and eight petal rose, pomegranate and cornflower. Accordingly, the old monumental gates of households in Maramureș are outstanding artworks with an archaic decoration featuring anthropomorphic, zoomorphic (the snake, the horse, the bird) and vegetal elements (the wheat ear, the fir tree, the tree of life) or other geometrical essentials that once had sacred meanings related to

[4] a large and culturally distinct Hungarian community in Transylvania fruitfulness and fertility rites. Such motifs are also present in the lyrics of traditional customs or in laments and funeral songs.

The simple form of the peasant house and its symbolic decoration is reflected also in religious architecture, the wooden churches representing an acme of Romanian folk art. Today 200 of the 600 existing wooden churches have been declared historical monuments ${ }^{5}$. In Transylvania, under the influence of Romanesque or Gothic architecture, the spire can be unbelievably tall for a wooden construction. Such is the case of the 18th century church of Urdeți, Maramureș, where it reaches $60 \mathrm{~m}$. The elegance of the lines and the harmony between the parts and the whole lend these churches a gracefulness that has made them famous worldwide.

The Transylvanian early voivode buildings substantiate influences of Romanic, Renaissance and Baroque stylistic styles mixed in original local syntheses, such as the Strei, Sfânta Maria Orlea and Densus churches in Hunedoara. The elements of the late Roman style coexist with the early Gothic at the Roman-Catholic cathedral in Alba-Iulia. The churches around Cluj respectfully nod to their Latin heritage, the most impressive of which is the St. Michael Roman Catholic Church, completed in 1480 and it was the first hall church in Transylvania. Besides the porch borrowed from lay buildings, in many zones, the churches also feature a tower. The main element in the Saxon architecture is also the church, which is always situated in the middle of the town. The Black Church, the cathedral in Braşov, was built in 1384 by the German community of the city and stands as the main Gothic style monument in the country, as well as being one of the most important Lutheran places of worship in the region. The churches of Sighisoara reveal 500-year-old frescoes, renaissance paintings, and Oriental carpets. In addition, the churches have been adapted to include defensive functions; all of them are either Romanesque basilicas or single-nave churches of the late Gothic period and often include many additions, ranging in age from the original period in which the churches were built late middle ages to the 16th century. Many churches also include baroque elements from that period, which was very popular in the region.

In the latter half of the 15 th century, the elements of mature Gothic are obvious in most religious edifices and in some of the lay ones in the main towns: Sibiu, Sebeș, Cluj, Mediaș, Braşov, and Sighişoara. Typical for the mediaeval architecture are also the fortifications ${ }^{6}$ of these towns, the most important one being in Sighişoara, with 14 towers bearing the names of the guilds that defended the town. The castles of the Hunyadi family in Hunedoara, the Bran Castle near Brasov, the peasant citadels and the fortified churches provide another example. Furthermore, different types of fortifications can be found: a small wall around the church, a row of fortifications or a real fortress with multiple

[5] http://www.worldheritagesite.org/sites/transylvania.html

[6] http://www.fortified-churches.com/locations 
fortification walls centred on the church. Elements of fortifications found in the main cities have been adapted, and they are a testimony of the building techniques used along the years by the Saxon community. Some fortifications had observations towers, some of them being church towers adapted to the needs of a fortress. The only buildings situated next to the fortifications are those of communal use the school or the village hall. Close to the church there is the main square of the village or Dance Square around which the social life gravitated. Around the square were situated the parish houses, along with the residences of the wealthiest villagers.

The present style of Transylvanian folk art crystallized at the beginning of the 18th century, including both Renaissance and Baroque elements, depending on the region. The main decorative themes were flowers and leaves, sometimes a bird or a spiral ornament, with a pigeon or a peacock's feather. Nearly all the manifestations of folk art flourished among the Transylvanian peasantry, their ceramics and textiles being the most highly developed of all.

The finest achievements in their textile arts are the embroideries, soft in line, and applied on altar cloths, pillow cases, sheets, and spectacular clothing, which vary from region to region. Those of Kalotaszeg (Ţara Călatei - 34 Hungarian villages in Cluj county) and Torockó (Râmetea in Cluj county) are fascinating products of Oriental design, full of charm and colour sewn chiefly in red, blue, or black. There is a symbolism in the colours used in the decorative work of the embroideries, thus black represents the soil from which life springs, red is the colour of summer, representing light and joy, and blue stands for grief and death. The famous writer Balázs Orbán (2014) describes the ancient customs and traditions in his famous description about the Szekler Land, so it was expected that a wealthy peasant family provide their marriageable daughter with a dozen ornate pillows, embroidered sheets, two to four decorated featherbeds, six to eight tablecloths and a dozens of dresses, for the most part richly embroidered. We can also find out that the pearly headbands (párta) worn by the girls are modelled after the noble ladies of earlier times, while their soft red leather boots with turned-up toes are Turkish derivatives. The Romanians living in the Kalotaszeg area have borrowed much from the Hungarians in clothing and footwear styles. The Romanian women's costume is fairly uniform over this area, consisting of an embroidered chemise and double apron, differing only in details of ornament. The men's varies even less, consisting of a tunic and narrow pants, either linen or wool, having a very medieval look. The Saxons unique folk wear is designed of silk, lace, velvet and other expensive materials, juxtaposed with ancient robes, made of leather and linen blended into a harmonious ensemble.

In the Transylvanian villages, where tradition is still strong, solemn moments or feasts are occasions for unique fashion parades. The cloth of folk costumes whether wool, cotton, linen or hemp used to be home-woven and everyone participated in costumes required by the moment, as well as by their age and social status. The folk costume is still worn and in some regions the colour combinations imposed by the tradition are strictly kept. In Harghita County the folk costume is kept even today in its original form, and it is distinguished among the different minorities that live in the villages from this region: Romanian, Hungarian, Szekler and Csángó $^{7}$. The peasant costumes are especially distinctive, preserving many ancestral motifs probably because of their ethnographic isolation. Accordingly, the Szeklers have been using hides to make clothes for many centuries. Both men and women wear leather jackets of various lengths and shapes, richly embroidered with traditional patterns. Another ancestral material long used by the Szeklers is broadcloth made of wool, which is still made and coloured with vegetable dyes. The tight, close-fitting men's trousers are made of this thick, stiff cloth, as are other garments, yet the women's skirts are always striped black, red, green and blue, are the usual colours. The Transylvanians have never been indifferent to beautiful clothes, thus fine taste, respect for tradition, the sacred and profane symbolism led to remarkable values.

Icons are used in homes to decorate, protect inhabitants, and sanctify the religious corner of the house, sometimes organized into small altars, and always placed on the eastern wall. At important road crossings and way stations, local residents erect small shrines and meditation spots, so that wooden or stone crosses and panels of religious scenes provide travellers places to pray and seek protection. The icon manufacturing has common sources for all the historical regions, being directly bound to the art of the Byzantine and Oriental tradition. The Romanian peasant house is never without icons, the sacred and the worldly standing in a natural harmony. Well known as a worship object, it also has an ornamental purpose. The icon manufacturing made on wood in the Byzantine style, uses formulas transmitted over the generations and demands time to be completed.

In the 17th-18th centuries the Romanian space boasted centres of icon painters who worked mostly on wood. A distinct genre is represented by icons painted on the back of glass panes, which began being crafted in Transylvania under a Central-European influence. The painted icons started appearing as a result of the engravings' interpretation. This kind of religious art became so popular that soon many villagers specialized in this art. As it got abroad in the domain of folklore, the glass painting represented the rural life as well as values of the villages. Both the icons made of wood and those painted on glass have common iconographic origins, traceable in the Byzantine iconography consolidated in the Orthodox Christian setting to this day and the motifs have been preserved by the peasant icon painter to a large extent. Nevertheless, the interpretation thereof is creative through the introduction into the religious thematic range of folk, anecdotal, or even jocular themes, which emerged from the observation of village life. Therein lays the iconographic individuality and originality of icon artisans in a traditional

[7] an ethnographic group of Roman Catholic faith with a Hungarian origin 
Romanian society imbued with holiness, yet conserving a mode of thought prone to rationality. The art of icon dyeing on wood was materialized especially in monasteries, in the monks' workshops, while icons made by painting glass were more widespread in the Transylvanian villages, the icon artisans' main occupation being agriculture. Their craft was transmitted in the family from generation to generation, along with the custom, models, and secret techniques. Some of them even founded schools for glass painting and their talent took them out of anonymity and the modesty specific to a religious spirit, a nameless painter of saints.

The art of making icons followed, consequently, three major directions: interpretations of the monasteries' frescoes and old engravings, replicas to the traditional icons, and images from the local habits and the occupations. The beauty of the Romanian icons made by painting glass lies especially in chromatics, which offers a harmony of colours of amazing subtleness. Highly original glass icon centres developed at Nicula, near Cluj, where painting on glass had become an art practiced by all the villagers, in the Schei district of Brașov, as well as in the Făgăraș and Sibiu zones. These centres had their heyday in the 19th century. The refinement and transparency of the painting, owed to the colours prepared by the painters themselves from natural products, the naive treatment of the religious themes and the harmonious combination between the narrative style and the decorative one account for the fame and value of these art objects. Each home used to have some 10 to 30 icons making up a genuine frieze. Today they are much sought after collector's items.

The renowned Transylvanian pottery plays an important role in the Transylvanian folk art and it is still vivid in numerous ethnographical regions with respect to its content of motifs, rules of composition, and colouring. Ancient traditions in the black, red or white pottery and the designs are unique to their areas as well as the ceramics are the most readily recognizable examples of this type of popular art, which is very close to the art represented by glass painting. A distinct place in traditional interior decoration is held by earthenware: plates, bowls, mugs and cups hanging on the walls or from girders. Complex patterns were actually secret languages known only to residents of the regions where they were painted. Before the availability of paint, the practitioner used different plant pigments to colour the mugs and bowls, which were chosen usually from plant leaves, flowers and tree bark that were then boiled. To obtain red colours, leaves of red onion or peony flowers were often used, yellow colours were derived from the apple tree bark or some yellow flowers, nut tree leaves were used to give a coffee-colour and raw rye of spring, the horsemint or the birch tree leaves were used to confer the green colour. The motifs that were chosen reflected the surrounding world and usually represented everyday life that gave this type of art a popular and realistic character. Most astonishing is the frequency of solar and star motifs, the sun appears as the symbol of spring, happiness and love of light. The phytomorph (plant) motifs expressing the beauties of nature are widely present in the painting, reflecting the Transylvanian folklore. From the generic 'leaf' and 'flower' to the snow drops as messengers of spring, through the pansies, trefoil, acorn of oak tree, fern, fir tree, the repertoire seems endless. Each motif is modulated according to the skill and personality of each 'painter'. The fewest representations are the anthropomorphic (man) motifs, which show man doing his job, his agricultural tool, or the figure of the shepherd who plays his whistle.

The folk pottery summarizes a series of traditional elements marked by the living conditions and by the evolution of the aesthetic taste. In Maramureș and Harghita counties, one can admire objects of black ceramics as well as objects of brush painted ceramics. Lăpusul Românesc is considered to be a synthesis of the Romanian earthenware forms' evolution. Another pottery centre in Maramureș is at Săcele where red unpolished ceramics is made, besides Vama (Satu Mare), Leheceni and Corund are famous for the enamelled ceramics splendidly decorated; centres with permanent ethnographical exhibitions and traditional fairs. In the earthenware centres, potters still use traditional techniques to craft glazed or unglazed, red or black ware, decorated with graffito or with applied colours, usually red, black, brown, yellow, green and white, while cobalt blue is characteristic of the Saxon pottery. In Transylvania pottery has had a millenary tradition, the museums boasting most valuable items dating back to the Neolithic.

\section{The Transylvanian Music}

The true spirit of Transylvania is best expressed into music. The nation produced a remarkable folklore, vividly expressed in the so-called Kuruc poetry and music. The Kuruc songs are among the finest in Hungarian music, but most of them existed only by oral tradition. They were collected and noted down by Ádám Pálóczi-Horváth in 1813. The Kuruc era produced a unique instrument, the tárogató, which is a double-reed woodwind instrument, similar to the oboe, with a penetrating sound. Luckily, it is very much in fashion in a modified form even today.

The roots of the Verbunkos go back to Hajdu dances but the presentation and special interpretation given by Gypsy musicians shaped all the elements into a style which left its imprint even on the art music of the $19^{\text {th }}$ century. The revolutionary influence of the Verbunkos changed all of the existing theatre music. The scripts of early plays had historical backgrounds and their style was inspired by Mozart and Rossini and many of the scenes and arias were composed in the Verbunkos style.

The Romanian folk song and dance is a loud, joyous music, usually accompanied by clapping of hands and singing, best expressed during the many seasonal or traditional festivals. The intensely rhythmic music is made primarily from three instruments: the cetera, a high-piercing violin; the zongora, a larger fiddle, and the doba, a goat-skin and wood drum. The dancers in folk costumes perform rousing, high-stepping and stamping dances in circles or with partners. Traditional accounts of George Enescu's musical development place great emphasis on the elements of 
Romanian folk music which appear in his works at an early stage - above all, in the Poème roumain (1897) and the two Romanian Rhapsodies (1901), as he remarked, the only thing a composer could do with an existing piece of folk music 'to rhapsodize it'. The real significance of his Romanian folkheritage would emerge later in the growth of Enescu's musical language, as he searched for new ways of developing, and combining, pure melodic lines.

The musical folklore knows three genders: lyrical, dramatic and epic. The lyrical gender includes the doina, a type of meditative song, frequently melancholic with an extended and flexible line in which melody and ornamentation merge into one; the songs of wedding and naturally of lament and work. The dramatic gender embraces the puppeteers, the evening sittings of the village women and the rain makers. The epic gender incorporates the ballads, the nuptial, the funeral and the old age songs. The folklore of the winter season, occasioned by Christmas and the New Year, is represented by mask games and wish-making.

The carol is one of the primeval musical genders, partly practiced by the church, with a rich profane content. Through the carol, wishes of thriving and happiness are addressed especially by groups of children or young people, sometimes accompanied by musical instruments. The mask games have a strong magic substratum, lost in the long runs preserved only as a musical ritual. The ballad, also called the old-age song, is sung on the occasion of gatherings, before an audience. A wide range, around 300 ballad themes are known among Romanians. The pastoral ballad 'Mioriţa' is the masterpiece of the gender.

The nuptial song and dance is very varied: vocal pieces the song of the bride, of the dawn, of the groom, of the mother-in-law; instrumental pieces - dance, marches, the basil, the dance of the bride, etc. The funeral folklore includes individual and group songs of lament, the down and the fit-tree, etc. The song of the dawn is very old and it is performed by women at the windows of the deported.

Romanian traditional melody is categorized by diversity, since its culture, which corresponds to important historical provinces, is characterized by relatively different tunes and interpretations. The basis of the tune is unified in character, with regional styles based on a few shared structural elements, such as the eight-unit meter pattern for songs and instrumental melodies, or the type of songs performed (the lyric song, the doina or 'long song', children's songs, the lullaby, and the epic song) as well as the genres of their ritual music (carols and ceremonial music, songs for fire purification, weddings and funerals, agricultural and pastoral songs).

Another characteristic is the musical instruments used, including simple and double pipes, the 'ocarina', harp, tree leaf, alpenhorn, fish scale and others. The earliest music was performed on various pipes with rhythmical accompaniment later added by a 'cobza'. This style can still be found in the Moldavian-Carpathian regions along with the Hungarian Csángó minority in Săcele (Brașov), and in Ghimeș (Harghita). The bagpipe was a popular instrument from medieval times, but became rare before the $20^{\text {th }}$ century revival. Since its introduction the violin has influenced the music in all regions by becoming the principal melody instrument. Each region has its own combination of instruments, old and new, and its own unique sound. This continues to progress to the present with the most recent additions being electric keyboards and drum sets.

The various Gypsy bands and their leaders, each of whom formed 'dynasties', were involved in popularizing the folkstyle songs, called nóta. Since the general population did not much care for the higher forms of music, symphonies, sonatas, and operas, it was the nóta that filled their musical needs. Although the nóta is not a folk song, because the songwriter's name is known, and because the writer uses intervals which do not appear in real folk songs, the songs are typically Hungarian, and in a certain mood everyone can find joy or consolation in singing or listening to one. Thus, several individual nótás, who composes the nóta, have had lasting popularity.

In the beginning of the $20^{\text {th }}$ century Béla Bartók (18811945), who was born in Timiş county, and Zoltán Kodály (1882-1967), two brilliant Hungarian geniuses became good friends and restless to create a new style of Hungarian music, reached out to the oldest origin, the almost forgotten peasant songs in Transylvania. Therefore, Bartók and Kodály spent several months together in remote villages, recording on wax cylinders the songs the village elders remembered, and finally in 1906 they published their first precious collection. Today, as a result of their efforts, an incredible 60,000 folk melodies are classified and preserved at the Hungarian Academy of Sciences.

Bartók and Kodály were subsequently appointed professors of the Academy of Sciences, the former as a piano teacher, and the later as a professor of composition. They successfully achieved a synthesis of Hungarian music and national character, creating their own masterpieces, which have gained international significance. Their language relies on folk music without repeating or imitating folk songs. In addition, both great musicians helped and developed the talents of many exceptional artists.

Next to his compositions, Kodály's great achievement also lies in the introduction of general musical education. In his cause, he propagated the ideas that music belongs to everyone, thus musical illiteracy, which prevents the simple people from enjoying higher levels of music, should be eliminated. Additionally, musical education has to be based on folk songs, as the musical heritage of the nation. He also confirmed that daily musical education contributed to the welfare of body and soul as much as does physical education, for that reason the basic foundation of musical culture had to be first vocal, and followed by instrumental studies.

The most important musician in the footpath of Bartók and Kodály was Sándor Veress, a pianist, musical folklorist, composer and lyrics writer. Born in 1907 in Cluj-Napoca, he studied piano with Bartók, and composition with Kodály to become the former's assistant in the folk-music department at the Academy in Budapest. Béla Bartók re-created the essence 
of Hungarian music with an inspirational force of the Hungarian folk songs from which he succeeded in creating a new musical genre from the soil of his land in the Carpathian Basin. The world-wide celebration held in his memory in 1981, elevated Bartók to a position in contemporary music equal in magnitude to Beethoven's in his own century.

An essential feature of the folk dancing is its highly 'improvisational' quality. Transylvanian village dancing does not have a 'fixed text'. There is no prescribed sequence of figures. In men's dancing, a man dances his own figures in his own preferred order, fitting his choices at least somewhat to the spirit and the impulse of the moment. When couples dance, they likewise assemble their own individual dance in keeping with the village tradition. Three aspects of improvisation deserve special discussion. First, improvisation is the fundamental mode of creativity and performance in traditional cultures where all artistic forms are based on variations within a tradition's stylistic inventory. Second, improvisation is a received skill, passed down from one generation of practitioners to another. Traditional musicians learn 'by ear'. Post-traditional musicians learn from scores. Like musicians, dancers are able to improvise within a tradition because they have assimilated both the 'grammar' and the 'vocabulary' of the dance, that is, both the units of expression and the rules for organizing them. Third, the survival of a high degree of improvisation is rare in modern times. Improvisation became impoverished in Western European regional ethnic dancing relatively early on. The Southern German Ländler dance forms, for instance, appear to have been improvised when settlers took them to Transylvania where they retained their free character. But those dances soon took on a fixed form in a fixed sequence of figures in Bavaria and Austria.

Transylvania offers not only a singular richness of dance and music traditions. It also provides insight into how improvisation once functioned in European dancing as it has until fairly recently in other traditional art forms. A great many villages now have dance ensembles - Romanian, Hungarian, and Saxon, and the revived dance forms are a mark of village identity and ethnic pride.

We can visit some Transylvanian villages where there is still at least a remnant of a village band and where elder dancers can still show their dances. These musicians and dancers often suffered under the repressive strategies of the Romanian government in the years leading up to 1989. During the totalitarian regime, the interest in Hungarians beyond Hungary's borders was tied to concerns for human rights. Yet many urban Hungarians came to see in the survivals of Transylvanian Hungarian dance and music a sort of confirmation or validation of their own cultural identities.

The folk music and dance of Romania prove that the Romanians are not a nation of resigned people. One of their typically folk instruments, the panpipe, has gained world fame, just like the Romanian folk music, owing to Gheorghe Zamfir's artistry. In the past the disco of young peasants was the village hearth, where they organized the hora, a merrymaking event that takes its name from a widespread round dance.

Many dances still practiced are connected to customs and holidays. One of the most beautiful is the dance of the căluşari, which young men dance in a syncopated rhythm during Whitsuntide which is a reminiscence of the Roman customs evoking the rape of the Sabine women. On all the stages of the world, enthusiastic applause has rewarded the young men who expressed in this dance the Romanians' bent for merrymaking and communication.

The last fifty years have brought changes to life in rural Transylvania which is analogous to those which occurred significantly earlier in most other areas of Europe: a transition from traditional village culture toward a posttraditional culture with more 'Westernized' features. In terms of Transylvanian village life, this shared cultural heritage resides principally in the traditions of the given community.

\section{Case Study Rationale}

Starting from the idea that language varies to a great extent across cultural boundaries and they are illustrative for the way in which linguistic and cultural constraints may affect the non-native speaker's fluency in a language, I thought it is as interesting as useful and challenging to make a comparative - contrastive study of intercultural awareness in order to see the extent to which these impacts have on educational cooperation practices and semantic features of cultural entities.

The recent emphasis on cognitive aspects in cognitive linguistic research need to be complemented by in-depth analyses of the real-world language, which provide and guide access to the conceptual domains. The reason for this kind of linguistic exploration is ingrained in the cognitive theoretical model, thus this section meant to be a contrastive study of cultural-linguistic data for reasons connected to the methodology of research and leaving room for future cross linguistic expansion.

The design of the case study sought to provide a rather detailed investigation meant to reveal how language resources are put to work in the use of cultural awareness and it is aimed to draw the cognitive linguistics and corpus linguistic traditions closer together through a qualitative analysis. The theoretical framework is broadly based on the cognitive theory and attention has been devoted to reveal the underlying cultural patterns, their conventionality with some of the correspondences and differences.

The thorough analysis of the motivations of intercultural awareness is expected to contribute to the cognitive theory of universality and culture-specificity in conceptualization. The present study is also considered to be relevant to cognitive linguistic research because it arises cultural awareness.

\section{Methodology}

Various informant testing was conducted to see whether students from Transylvania would be able to 'make sense' of the importance of cultural identity. The purpose of this experiment was to see how and to what extent the common heritage topic helps informants to realize the importance of 
intercultural values in a multicultural environment.

In the conduct experiment I provide additional support for the idea that awareness and acquisition of the cognitive structure of meanings give support to vocabulary teaching and learning. I hypothesised that learners, who know the importance of intercultural values, will figure out and keep in mind the multicultural assessment more easily than students who do not have such comprehension. I carried out a series of experiments, the results of which support this hypothesis. Accordingly, it is suggested that the motivational factors of the intercultural values should be clarified to students in the language classroom in order to achieve better results.

In the experiments I have assessed the effect of principles having an impact on educational cooperation practices and semantic features of cultural entities. The experiments also involved students' awareness of intercultural and multicultural motivations. I have also examined whether similar effects on the learning of cultural values can be obtained under task designs that offer students less explicit guidance and which thus give confidence to learner autonomy. Therefore, students were given the task of identifying cultural canons themselves, while they were presented with pictures illustrating unstated cultural principles to stimulate dual coding.

The results of the experiments have been analysed with a view to providing steps towards concrete classroom applications. Variation in ways of presentation and differences among learners, both have the prospective to deeply influence the effectiveness in particular classrooms of the pedagogical techniques for advancing cultural awareness. Particular variables suggested include the characteristics of the cultural morals to be taught, cross-linguistic considerations, task design, and possibly learner characteristics such as level of proficiency and aptitude.

Discussion

The materials carried out in the experiment were first piloted with second-year college students majoring in Marketing, studying English at an intermediate level, approximately B1 level ${ }^{8}$. After the pilot, the material was adjusted with the revision being used in the actual experiment. As the materials seemed to entail a high level of linguistic knowledge on the part of the students, it was decided to accomplish the actual experiment with participants of a more advanced level of proficiency.

Participants in this experiment were two parallel groups of first year English majors at 'Sapientia' Hungarian University of Transylvania. The students were 19-22 years old and their level of proficiency in English was upper-intermediate, approximately B2 level. The control group consisted of 20 students and the experimental group consisted of 25 students.

As a pre-test to compare their proficiency, it was used the students' grades in their 'Testing' colloquium, which was part of their preparation for the end-of-year exam. The grades revealed no significant difference between the two groups. The experiment employed identical material and instruction

[8] according to the descriptors in the European Framework of Reference in both groups, with one main exception: the organization of the cultural connotations to be learned. The experiment consisted of two testing; both designed to examine the effects of learners' knowledge of intercultural motivations. Both assessments employed the same materials and similar, though not identical, procedures. The pilot study had revealed that all the students were familiar with the lexis targeted in the experiment.

The method used in these experiments consisted of two one-page handouts. The first sheet presented the input: a test containing 20 questions regarding intercultural knowledge. The second sheet contained a gap-filling test. Students in both groups were familiar with the most frequently used concepts, as well as the central meanings of the given context. Nevertheless, examples of these meanings were also included in the teaching and testing process, since the general meanings and cultural concepts that would be targeted in the experiment largely depended upon these meanings.

The only difference between the experimental and the control group was in the manner of presentation of the cultural connotations to be taught. While the control group were taught the English concepts through Hungarian 9 equivalents, the experimental students were taught in accordance with the Cognitive Linguistics approach, consequently, I explained the most important motivating factors to them.

For each group, the instruction stage and the administration of the test were divided into two parts within the framework of a 100-minute seminar. Gap-filling tests followed each of the stages of the tutoring procedure, as well as one day after the two-stage lessons an immediate testing process, a post-test was administered to each group.

Results

The responses to the immediate-test and the post-test of both groups were analysed, taking into account the completely correct responses, then including cultural comprehension in the second part of the tests, which were not entirely correct but in which the key concepts were given correctly. The reason for not excluding these answers was to see whether students were able to make a distinction between the senses of cultural connotations, which was the primary aim of the testing, after all.

In both the immediate test and the post-test, the experimental group outperformed the control group, and a statistical significance was also obtained across the board. The difference between the immediate test and the post test shows that the performance by the experimental students increased on average by $25 \%$, whereas the performances of the control group increased by only half this rate, $12 \%$.

The experimental group did noticeably better in the two tests. Including target word-type answers, they actually obtained scores in the post-test of $97 \%$, while the control group $85 \%$. The scores in the assessment prove the development of the experimental group; specifically, the experimental group outperformed the control group and 
especially in the post-test. Taking only completely correct responses into account, defer a non-significant result for the immediate test, but a significant for the post-test. Counting not completely correct responses, significant levels are achieved for both tests.

On the whole, the experimental results support the hypothesis that the precise knowledge of motivated meanings in the experimental group help students to become culture conscious better than other learners who only learn about culture at home on their own. Accordingly, maintenance of the multiple senses and uses of cultural awareness can be improved by employing insights from cooperation cultural practices. The results of the experiments indicate that a unique revelation is not satisfactory to turn intercultural awareness into a learning strategy for the future processing of representative lexis. A more extensive curriculum seems to be needed to accomplish this, and despite that, individual differences would continue to play a part.

In conclusion, our conceptual knowledge in principal consists of cultural models and such models can be thought of as prototype-based conceptual structures or schemas. An emotion concept is prototypically understood as a sequence of events beginning with a set of "antecedent conditions", a set of "behavioural responses" and a set of "self-control procedures" (Shaver et al. 1987).

As I would expect, the limitations of the experiments because of the number of participants make it impossible to represent definitive and general conclusions concerning teaching intercultural awareness. The experiments could be simulated or developed in several ways. I am also aware that various teaching strategies may correlate and in cooperation determine learning results, so it is hard to separate the variables that best lead to learning. Many questions remain, and further research is needed to conclude, for example:

(1) How much explicit educational practice is required to increase learners' cultural awareness adequately to apply it effectively and independently as a learning strategy?

(2) To what extent would students be inclined to appreciate the significance of this kind of teaching?

\section{Conclusions}

The Transylvanian culture remained relatively unaffected, Romanians, Hungarians, and Saxons have lived in mixed villages or in close proximity and although each ethnic group maintained its own traditions, they influenced one another profoundly, as they have evolved side by side, and their importance is helping to define the values of the society in which they were set. Consequently, every one of the "nation parts" has been enriching its "nation whole" for centuries, yet these people managed to contribute to one another while adhering to their own particularities, and created a tolerance zone in this experimental fairyland, which was unprecedented in history, a working model for the equalitybased cohabitation of communities of varied identities. What was wonderful about this arrangement was that none of the parties had anything to lose, all participants gained by it.

This wonderful land is a veritable ethnographic paradise: picturesque costumes, characteristic architectural motifs, interesting folklore, beautiful songs and a store of popular wisdom brought from distant regions are stored here. The churches marking the eastern frontier of Gothic art face the western outposts of Greek orthodoxy and this variable scenery is formed into an amazing unity by the semicircle of the Carpathians. The interdependence of nature as well as people has created a remarkable atmosphere, an identity of mood, which pervades the diversity of local heritage. Transylvanians attach significance to buildings and to places and within each of the regions the built heritage has played a distinctive role in helping to define the values of society, since they define local distinctiveness, identity, they can engender local pride and can reflect the quality of life and society. Their architecture, design and use are an integral part of their cultural identity in which they exist. On the other hand, they possess also a Transylvanian value, a joint heritage, to be used and enjoyed by all its citizens.

Overall, Transylvania is a land of unique historical and cultural experiences, one the Global Heritage Fund is working to bring to life for adventurous travellers. The territory has undergone many political, social and cultural changes during the years through wars, revolutions and political maneuverings, resulting in a redefinition of boundaries, a redistribution of people and a need for clearer understanding between cultures at many levels of society. Despite political changes, Transylvania will remain forever unconquerable, a mysterious, self-contained entity which neither the East nor the West will ever make completely its own, never fully understood except by her own children, never fully manifesting herself except to them.

\section{References}

[1] Baker, W. 2012. From cultural awareness to intercultural awareness: culture in ELT. ELT Journal, 66 (1), 62-70

[2] Bartók, Béla. 1981. The Hungarian Folk Song, with annotations by Zoltán Kodály. The New York Bartok Archive Studies in Musicology 13. Albany: State University of New York Press.

[3] Brukenthal Museum Sibiu. Available: http://www.brukenthalmuseum.ro/index_en.htm

[4] Byram, M. 2008. From foreign language education to education for intercultural citizenship: essays and reflections. Clevedon: Multilingual Matters Ltd.

[5] Clyne, M. 1994. Inter-Cultural Communication at Work. Cultural Values in Discourse. Cambridge, UK: CUP.

[6] Fortified Churches in Transylvania. Available: http://www.fortified-churches.com/locations;

[7] Gudykunst, W. B., \& Lee, C. M. 2002. Cross-cultural communication theories. In W. B. Gudykunst \& B. Mody (Eds.), Handbook of international and intercultural communication $\left(2^{\text {nd }}\right.$ ed., pp. 25-50). Thousand Oaks, CA: Sage. 
[8] Orbán, Balázs. 2014. A Székelyföld Leirása: Történelmi, Régészeti, Természetrajzi S Népismei Szempontból. United States: Nabu Press

[9] Risager, K. 2007. Language and culture pedagogy. Clevedon Multilingual Matters.

[10] Shaver, P., J. Schwartz. D. Kirson. and C. O'Connor. 1987. 'Emotion knowledge: Further exploration of a prototype approach'. In Journal of Psychology and Social Psychology 52: 1061-1086.

[11] Sinclair, J. 2004. Trust the Text: Language, corpus and discourse. London: Routledge.

[12] Traditional Culture and Folklore. Available: http://portal.unesco.org/en 